\title{
Early-handling and social-rearing effects on dominance-subordination behavior in the adult rat
}

\author{
GILBERT BECKER and GERARD \\ EZINGA, University of Manitoba, \\ Winnipeg, Canada
}

Effects of early handling and social rearing on dominance behovior were studied using the method of fixed-pair comparisons. Handled rats (in competition with nonhandled controls) were dominant, especially where both competitors were raised in social isolation. Socially-raised rats (in competition with isolation-raised rats) were dominant but only where both competitors were early-handled.

Physical stimulation (usually tactual or electrical) and social stimulation (living in the home cage with other rats) are two earlyexpe iential factors which may influence the learning of social-dominance habits in the adult rat. Two problems exist, however, which seem to preclude the drawing of definitive empirical generalizations concerning the effects of either or both of those factors. One problem stems from the use, in almost all instances, of rotated-pair comparisons in observing social dominance. Probability values derived in such cases for drawing inferences concerning population differences may reflect the results of (a) the experimental manipulation in interaction with serial effects based on stimulus generalization (Becker, 1965), or (b) sampling error in interaction with serial effects based on stimulus generalization (Seward, 1946). In either case, the experimental effect is exaggerated or nonexistent. One way to control for such serial effects is to make use of nonrotated or fixed-pair comparisons.

The other problem relates solely to the effects of social stimulation. Some reports indicate that social rearing facilitates the learning of social-dominance habits in a competitive situation or the spontaneity of aggression in either a foot-shock or neutral situation (Hutchinson, Ulrich, \& Azrin, 1965; King \& Gurney, 1954; Rosen \& Hart, 1963; Thompson \& Melzack, 1956). Other reports suggest the opposite (Ginsburg \& Allee, 1942; Janssen, Jageneau, \& Niemegeers, 1960; Uyeno \& Benson, 1965; Uyeno \& White, 1967; Ward \& Gerall, 1968; Yen, Stanger, \& Millman, 1958). Still others find no difference (King, 1957; Rosen, 1961; Rosen \& Hart, 1963). These differences could be explained in terms of task requirement (Uyeno \& White, 1967), demand- stringency (Uyeno \& White, 1967), definition of isolation (King, 1957), size of the social group (Rosen, 1961), or strain differences (Rosen \& Hart, 1963). Regarding the effects of physical stimulation, there is total agreement over the three reported studies that early stimulation facilitates the learning of social-dominance habits (Becker, 1965; Mezei \& Rosen, 1960; Rosen, 1958). However, in all three cases, the rotated-pair comparisons method was used. The present study sought to uncover any existing interactions between physical and social stimulation while making use of the fixed-pair comparisons method.

\section{SUB̀JECTS AND APPARATUS}

Subjects were 80 naive male rats of Sprague-Dawley derivation. They were born of timed pregnants purchased from Holtzman Co. and delivered during the early part of the third trimester of gestation.

The apparatus used for the observation of dominance and subordination behavior is described and illustrated elsewhere (Becker, 1965). It is a rectangular box with a wooden floor, wooden sides, and a removable Plexiglas top. A platform extends from each end on which a home cage can be secured on its side. When the guillotine door at either end of the box is raised, the rat in the cage can approach the contents of the plastic cylindrical container screwed to the center of the floor

\section{PROCEDURE}

Pups in even-numbered cages were systematically handled once each day on Days 6 through 17. The handling sequence consisted of placing the mothers in an empty cage, picking up each pup individually, stroking its back and neck while transporting it to an adjacent room, placing the pup into a wax-coated paper container, leaving the pup in the container till the remaining pups in the litter had been similarly treated (mean stay approximately $2.5 \mathrm{~min}$ ), bringing each pup back to the home cage, again individually and in the same order and with the same stroking of back and neck, and replacing the mother when all pups had been returned. Pups in odd-numbered cages were left untouched. Ss were separated from their mothers on Day 21 and sexed. On Day 23, half the male Ss within each treatment group were placed into individual cages and the other half, four to the cage. From each of the four cross-classification groups, 20 rats were selected at random for observation in the dominance box.

Habituation to the box began on Day 58, at which time the rats raised together were placed into individual cages and a 12-g-per-day feeding schedule was inaugurated for all $\mathrm{Ss}$ and maintained for the duration of the experiment. The procedure consisted of placing a home cage, with $S$ inside, laterally on one of the cage platforms. $S$ was then permitted, over a $2-\mathrm{min}$ period, once each day, to pass through the raised door, explore the box, and eat the wet mash placed in the food container. When $S$ was able to reach the food container in $.05 \mathrm{~min}$ or less after the guillotine door was raised, it was excluded from further habituation runs. On later trials, laggards were given up to $5 \mathrm{~min}$ to help catch up. On Day 77 all Ss had reached criterion and on the following day were given one final habituation trial.

Competitions began on Day 79. The same two Ss making up each of the 40 fixed pairs were permitted to compete for food over 155 -min trials, 1 trial per day. On a given competition, two home cages, with $S$ inside, were placed one on each cage platform. The two doors were raised simultaneously, permitting each $S$ to approach the food container with equal advantage and compete for the wet mash available to only one $S$ at a time because of the small diameter ( $1 \frac{1 / 4}{4}$ in.) of the food container. A separate Hunter Clockounter was used for each $S$ to record the accumulated time $S$ spent eating at (dominating) the food container. Tails were colored to facilitate recognition.

PAIRING ARRANGEMENT

What seems to be at first glance a simple 2 by 2 factorial arrangement is not feasible unless one is willing to rotate pairings between a given $S$ in one interaction group (cell) and all Ss in the remaining three cells (Uyeno, 1960). In using fixed pairs, however, one resorts in the present situation to what functionally is two different experiments.

Experiment 1

In the first arrangement 10 handled Ss raised in group cages were randomly pitted against 10 nonhandled $S s$ also raised in group cages. Likewise 10 handled $\mathrm{Ss}$ raised in isolation were paired with 10 nonhandled Ss also raised in isolation. The accumulated time scores of the handled rats were converted into percentages indicating the amount of time members of that group spent eating at the container 
ciative to the total amount of time both the handled and nonhandled rats spent cating at the container.

Experiment 2

In the second arrangement 10 socially. raised Ss that were early handled were randomly paired with 10 isolation-raised Ss that were also early handled. Sinilarly, 10 socially-raised $S$ s that were nonhandled were randomly paired with 10 isolationraised Ss that were also nonhandled. The accumulated time scores of the sucially. raised rats were converted into percentages and handled similarly to those in Experiment 1 .

\section{RESULTS AND DISCUSSION}

For statistical purposes, the 15 trials were collapsed in to three blocks of five trials each. Each block mean was tested for significance against a hypothetical mean of $50 \%$, the value to be expected when nothing but chance factors are operative. The results of Experiments 1 and 2 are summarized in Tables 1 and 2, respectively. In comparing the four groups, we find in first rank the handled rats (in competition with nonhandled rats) where both groups were raised in isolation ( $\mathrm{H} / \mathrm{N}$ under ISO). Tied for second rank are the handled rats (in competition with nonhandled rats) where both groups were raised in group cages $(H / N$ under $S O C)$ and the socially. raised rats (in competition with isolationraised rats) where both groups were early handled ( $\mathrm{S} / \mathrm{I}$ under HAN). In last place, and very close to chance expectation, are the socially-raised rats (in competition with isolation-raised rats) where both groups were nonhandled ( $\mathrm{S} / \mathrm{l}$ under NON). The increasing trend over trial blocks in the $\mathrm{H} / \mathrm{N}$ under ISO group is the only such trend among the four groups but is only peripherally significant $(A=.325, p<.10$ between means of Blocks 1 and 3 ). The

Table 1

Percentage Score of Early-Handied (in Competition with Nonhandled) Rats Reared Either in a Social or Isolation Postweaning Environment

\begin{tabular}{cccl}
\hline Group & Mean & \multicolumn{1}{c}{ SD } & \multicolumn{1}{c}{ ta $^{\mathrm{a}}$} \\
Social Block 1 & 56.6 & 8.50 & $2.45^{*}$ \\
Social Block 2 & 57.2 & 10.63 & 2.14 \\
Social Block ? & 57.0 & 9.57 & $2.31^{*}$ \\
& & & \\
lsolate Block 1 & 56.5 & 13.62 & 1.51 \\
lsolate Block 2 & 60.8 & 13.40 & $2.55^{*}$ \\
lsolate Block 3 & 62.3 & 11.23 & $3.46^{* *}$ \\
\hline
\end{tabular}

a The t test is between the mean obtained percentoge and the hypothetical mean percentage af 50 . which is to be expected when nothing but chance lactiors arc operatile.

$* p<.15$ twe-tailod

$* * p<01$ invirtailed!
Table 2

Percentage Score of Socially-Raised (in Competition with Isolation-Raised) Rats Either Given Preweaning $T$ actual Stimulation or Left Undisturbed

\begin{tabular}{lrrr} 
Group & Mean & \multicolumn{1}{c}{ S1) } & $\mathbf{t}^{\mathrm{a}}$ \\
andled Block 1 & 56.0 & 8.15 & $2.33^{*}$ \\
andled Block 2 & 56.2 & 7.07 & $2.77^{*}$ \\
andled Block 3 & 56.9 & 7.74 & $2.82^{*}$ \\
& & & \\
ontrol Block 1 & 54.7 & 8.72 & 1.70 \\
ontrol Block 2 & 50.3 & 8.46 & $<1.00$ \\
ontrol Block 3 & 49.8 & 10.26 & $<1.00$
\end{tabular}

a The $t$ test is between the mean obtained percentage and the hypothetical mean percentage of 50, which is to be expected when nothing but chance factors are operative.

* $p<.05$ (two-tailed)

$* * p<.02$ (two-tailed)

greater dominance in the $\mathrm{H} / \mathrm{C}$ under ISO group relative to the $\mathrm{H} / \mathrm{C}$ under $\mathrm{SOC}$ group with respect to chance expectation is in ratio close to $2: 1$, but the difference between the groups' means (Block 3 ) is not significant $(t=1.13)$.

The superiority of the early-handled rats is consistent with previous reports and confirms the importance of early handling in the determination of social behavior. The superiority of the socialates among early-handled rats but not among nonhandled controls suggests another source of the null findings reported in other studies. The interaction further suggests that the social behaviors learned during group rearing that facilitate social dominance are either learned only among the less emotionally reactive individuals or are learned by all individuals but are ineffective among the more highly emotionally reactive during stress situations.

Two studies in which rats were used reported that isolates. were superior to socialates. In the first (Uyeno \& White, 1967) the authors suggest that although under the usual conditions of testing the socially-raised rat is superior, this superiority is reversed where "maximally demanding conditions necessary to arouse survival motivation" exist, or more specifically, where losing means death by drowning. In the second study (Ward \& Gerall, 1968) the authors report the same superiority reversal but under the nonmaximally demanding conditions associated with competition for food. Since both studies used a similar apparatus, in which ablity to pusl an opponent along a confining alley was the basis for defining dominance, it secms that this ability and not survival motivation was responsible for the superiority reversal. We agree with Ward and Gerall that dominance-subordination may be a result of demand characteristics of the situation and organismic variability.

\section{RIIERENCES}

BECKER, G. Social dominance and subordina tion in the rat as a function of postweaning electrical stimulation. Joumal of Genetic Psychology, 1965, 107, 349-369.

GINSBURG, B., \& ALLEE, W. C. Some effects of conditioning on social dominance and subordination in inbred strains of mice. Physiological Zoology, 1942, 15, 485-506.

HUTCHINSON, R. R., ULRICH, R. E., \& AZRIN, N. H. liffects of age and related factors on the pain-aggression reaction. Journal of Comparative \& Physiological Psychology, $1965,59,365-369$.

JANSSEN, P. A. J., JAGENEAU, A. H., \& NIEMEGEERS, C. J. E. Effects of various drugs on isolation-induced fighting behavior of male mice. Joumal of Pharmacology \& Experimental Therapeutics, 1960, 129, $471-475$.

KING, J. A. Relationships between early social experience and adult aggressive behavior in inbred mice. Joumal of Genetic Psychology, $1957,90,151-166$.

KING, J. A., \& GURNEY, N. L. Effect of early social experience on adult aggressive behavior in C57BL/10 mice. Journal of Comparative \& Physiological Psychology, 1954, 47, 326-330.

MEZEI, T. C., \& ROSEN, J. Dominance behavior as a function of infantile stimulation in the rat. Archives of General Psychiatry, 1960, 3, 53-56.

ROSEN, J. Dominance behavior as a function of post-weaning gentling in the albino rat. Canadian Journal of Psychology, 1958, 12, 229-234.

ROSEN, J. Dominance behavior of the adult rat as a function of early social experience. Journal of Genetic Psychology, 1961, 99, 145-151. ROSEN, J., \& HART, I. M. Effects of carly social isolation upon adult timidity and dominance in peromyscus. Psychological Reports, 1963, 13, 47-50.

SEWARD. J. P. Aggressive behavior in the rat: IV. Submission as determined by conditioning, extinction, and disusc. Joumal of Comparative Psychology, 1946, 39, 51-76.

THOMPSON, W. R., \& MELZACK, R. Early environment. Scientific Anerican, 1956, 194, 38.42.

UYENO, E. T. Hereditary and environmental aspects of dominant behavioz in the albino rat. Journal of Comparative \& Physiological Psychology, 1960, 53. 138-1 +1.

UYINO. F. T., \& BFNSON, W. M. Iffects of lysergic acid diethylamide on attack behavior of male albino mice. Psychopharmacologia. $1965,7,20-26$.

UYENO, I. T., \& WHITE, M. Social isolation and dominance behavior. Journal of Comparative \& Physiological P'sychology, 1967, 63, 157-159.

WARD. 1. L., \& GIRALL. A. A. Dominance behavior in socially isolated rats. Psychonomic Science, 1968. 13. 39-40.

YIN. H. C. Y., STANGER, R. L.., \& MILIMAN. $N$. Isolation-induced degressive behavior in ataractic test. Joumal of Pharmacology \& lisperimental Therapleutics. 1958, 122.85. 